\title{
Wheat root growth responses to horizontal stratification of fertiliser in a water-limited environment
}

\author{
Kemo Jin • Jianbo Shen • Rhys W. Ashton • \\ Rodger P. White • Ian C. Dodd • Martin A. J. Parry • \\ William R. Whalley
}

Received: 21 May 2014 / Accepted: 18 August 2014 / Published online: 30 August 2014

(C) The Author(s) 2014. This article is published with open access at Springerlink.com

\begin{abstract}
Background and aims We were interested to determine the effects of horizontal stratification of nutrient-rich zones within different layers of the soil profile in water-limited environments on root growth and crop yield. This is practically relevant to large areas of China, many of which have been over-fertilized.

Methods We used soil-filled rhizotrons $1.4 \mathrm{~m}$ deep to grow wheat. Three different nutrient-rich horizontal stratifications were used at depths of 0-40, 60-100 and $0-140 \mathrm{~cm}$. The soil was packed to a density of $1.5 \mathrm{~g} \mathrm{~cm}^{-3}$, at a matric potential of $-10 \mathrm{kPa}$. The wheat was grown until it was at terminal drought. Low soil hydraulic conductance preserved the horizontal nutrient stratification.

Results Plants grown in rhizotrons with a surface layer $(0-40 \mathrm{~cm})$ of nutrients had the greatest root growth, water uptake and yield. When nutrients were uniformly
\end{abstract}

Responsible Editor: Martin Weih..

K. Jin $\cdot$ J. Shen $(\bowtie)$

Department of Plant Nutrition, College of Resource and Environmental Sciences, China Agricultural University,

Beijing 100193, China

e-mail: jbshen@cau.edu.cn

K. Jin · R. W. Ashton • R. P. White - M. A. J. Parry •

W. R. Whalley $(\bowtie)$

Rothamsted Research, West Common, Harpenden,

St Albans AL5 2JQ, UK

e-mail: richard.whalley@rothamsted.ac.uk

I. C. Dodd

The Lancaster Environment Centre,

Lancaster University LA1 4YQ, UK distributed throughout the rhizotron $(0-140 \mathrm{~cm})$, root growth was restricted to the surface layer. Measurements of soil moisture indicate this was because the roots became impeded.

Conclusions Nutrient enrichment of the surface layer was the most effective at promoting deep roots, higher water uptake and yield under water-limited conditions. Heterogeneous nutrient distribution can modify root growth and water uptake.

Keywords Root proliferation - Water-limited . Horizontal nutrient stratification $\cdot$ Wheat

\section{Introduction}

Water is essential for crop production because plants need water for growth and tissue expansion (Morison et al. 2008; Wilkinson and Davies 2010). However, China's water availability per capita is only one quarter of the world average (Wang et al. 2008b; Du et al. 2010). The outlook for water shortage is especially dire on the North China Plain, one of the main grain production areas in China (Kendy et al. 2003; Deng et al. 2006; Wang et al. 2008a; Hu et al. 2010b; Fan et al. 2012). The region comprises $33.8 \%$ of the national arable land of China, but has only $3.85 \%$ of the national water resources (Fan et al. 2012). The relationship between grain yield and water-use has been described by the Passioura equation ((Passioura 1977), Grain yield $=$ Transpiration $\times$ Transpiration efficiency $\times$ Harvest in$d e x)$. Increases in any of these three components will 
translate into greater yield. Thus, there is a need to develop new genotypes and/or improve management of cropping systems to maximise water-use efficiency and/or water uptake. Of particular importance is how nutrient distribution within the soil profile affects root growth and hence water uptake.

On the North China Plain there is an intensive farming system which has over-used nutrients (about $550 \mathrm{~kg} \mathrm{~N} \mathrm{ha}^{-1} \mathrm{yr}^{-1}$ applied to two crops per year) for decades, based on the traditionally assumed notion of 'high input, high output' (Zhang et al. 2012; Shen et al. 2013). Excessive fertilizer (especially N) application and poor management has contributed to high soil nitrate- $\mathrm{N}$ accumulation and losses of $\mathrm{N}$ to the environment (Ju et al. 2006; Qiu et al. 2012). Soil $\mathrm{NO}_{3}{ }^{-}-\mathrm{N}$ enriched in the top 90 or $100 \mathrm{~cm}$ of the soil was above $200 \mathrm{~kg} \mathrm{~N} \mathrm{ha}^{-1}$ under conventional $\mathrm{N}$ practice in intensive wheat-maize systems (Liu et al. 2003; Cui et al. 2008). When soil nitrate levels are high, root biomass and root to shoot ratio decrease, more roots are found in the topsoil layer and root growth, especially of lateral roots, is depressed (Durieux et al. 1994; Wang et al. 2003; Mi et al. 2010).

A larger proportion of root biomass located in deep soil layers can maintain greater transpiration rates (Lopes and Reynolds 2010). Modelling work has concluded that root system architecture, with a larger investment in fine roots deep in the soil, will increase crop yields by accessing extra soil water resources from the whole soil profile (King et al. 2003; Lynch and Brown 2012). The promotion of water captured from subsoil by dryland wheat (Tritcum aestivum L.) can make a big contribution to yield (Kirkegaard et al. 2007; Richards 2008; Lilley and Kirkegaard 2011). Increasing root system access to water deep in the soil profile may be a promising way to increase water capture under waterlimiting conditions (Mi et al. 2010; Dodd et al. 2011; Jin et al. 2013; Trachsel et al. 2013; White et al. 2013). However, whether the site of nutrient application can regulate root growth, thereby altering crop water-use, is an important issue that may increase crop productivity under water-limited conditions (Hodge 2010; Jin et al. 2013; Shen et al. 2013), but this issue has been relatively unexplored. Soil nutrient heterogeneity must be considered when designing soil management strategies aimed at improved overall resource use efficiency, particularly water-use efficiency (Farley and Fitter 1999; Fransen et al. 1999; Hodge 2004; Tittonell et al. 2005; Hodge 2006; De Kroon 2007). However, the evidence on the role of spatial heterogeneity of soil nutrients on plant growth has been acquired mainly from studies of nutrient patches (Hodge 2004; Hutchings and John 2004; Wang et al. 2013). These "nutrient pocket" studies are not so relevant to understanding the intensive farming system in China where pronounced vertical nutrient gradients have developed due to surface nutrient applications and flood irrigation (Zhu and Chen 2002; Ju et al. 2004; Hu et al. 2005; Fang et al. 2006; Fan et al. 2012). Fang et al. (2006) found that under a lower level of soil moisture content ( $70 \pm 15 \%$ of field capacity), high $\mathrm{N}$ application rate $\left(300 \mathrm{~kg} \mathrm{~N}\right.$ ha ${ }^{-1}$, surface broadcast) significantly increased $\mathrm{NO}_{3}{ }^{-}-\mathrm{N}$ content in the topsoil and soil profile below $40 \mathrm{~cm}$.

Although Drew and co-workers (Drew 1975; Drew and Saker 1975; 1978) have shown that roots proliferate in nutrient-rich stratified layers, these were well-watered (continuously irrigated with nutrient solution). However, primary root length is regulated by water availability rather than nitrate supply (Forde and Zhang 1998; Walch-Liu and Forde 2008; Chapman et al. 2011). Even in sand culture systems the elongation of primary roots increases with decreasing water availability irrespective of root surface nitrate availability (Chapman et al. 2011). That root physiology responds to water potential is well reported (Sharp et al. 1988; Verslues et al. 1998; Whalley et al. 1998; Van Der Weele et al. 2000; Roycewicz and Malamy 2012). In this work, we explored the effects of horizontal stratification of nutrientrich zones on root growth and water capture when the soil profile is allowed to dry, and hence water-limited. Three possible scenarios of relevance to large areas of China's intensive agriculture (Fan et al. 2012; Zhang et al. 2012; Shen et al. 2013) were simulated (1) uniformly nutrient-rich profile, (2) nutrient-rich surface layer and (3) a nutrient depleted surface layer with nutrient-rich layer at depth. We tested the hypothesis that a heterogeneous nutrient distribution with depth will increase root growth and hence water uptake in comparison with a uniform (homogeneous) soil profile.

\section{Materials and methods}

\section{Plant material}

Seeds of a Rht-B1a NIL (near isogenic line) in a Mercia background were germinated between two sheets of wet filter paper (Whatman No. 1, $150 \mathrm{~mm}$ diameter) in Petri 
dishes which were wrapped in black nylon fabric to exclude light.

\section{Soil}

We used a loamy sand soil (Butt Close, see also Whalley et al. 2008) obtained from Rothamsted experimental farm at Woburn, Bedfordshire, UK. It had $87.5 \%$ sand, $5.5 \%$ silt and $7.2 \%$ clay and organic carbon content of $1.0 \%$ (by weight). The water release characteristic of the soil was measured with standard laboratory methods (Gregory et al. 2010).

Experimental treatments and approach

To investigate the effects of root response to nutrient distribution, plants were grown in rhizotrons: 145 (high) $\times 38.8$ (wide) $\times 8$ (deep) $\mathrm{cm}($ Fig. 1$)$. One wall of the rhizotron was glass and during the experiment they were inclined at approximately $15^{\circ}$, which allowed the roots to follow the glass face. We used three types of nutrient placement: (1) Uniform (0-140 cm, nutrient-rich at all soil depths), (2) surface soil of 0 to $40 \mathrm{~cm}$ and (3) deep layers of 60 to $100 \mathrm{~cm}$. The experiment was carried out in a controlled environment (CE) room with day/night temperatures of 22 and $18{ }^{\circ} \mathrm{C}$, respectively, and a $14 \mathrm{~h}$ day length. The relative humidity was $70 \%$ during the day and $80 \%$ at night. Lighting was by fluorescent tubes, with supplementary tungsten lighting, and the photosynthetic photon flux density was 450 $\mu$ molm $^{-2} \mathrm{~s}^{-1}$ at plant height.

The soil was packed to a bulk density of $1.5 \mathrm{~g} \mathrm{~cm}^{-3}$. In nutrient poor areas, deionised water was added to the loamy sand soil and mixed evenly to raise the moisture content to the required level $\left(170 \mathrm{~g} \mathrm{~kg}^{-1}\right.$, gravimetric soil moisture content) to give a matric potential of -10 $\mathrm{kPa}$. In the nutrient-rich areas, Hoagland's standard solution $\left(\left(\mathrm{Ca}\left(\mathrm{NO}_{3}\right)_{2} .4 \mathrm{H}_{2} \mathrm{O} 2.00 \mathrm{mM}, \mathrm{KCl} 4.00 \mathrm{mM}\right.\right.$, $\mathrm{CaCl}_{2} \cdot 2 \mathrm{H}_{2} \mathrm{O} 4.00 \mathrm{mM}, \mathrm{MgSO}_{4} .7 \mathrm{H}_{2} \mathrm{O} 2.00 \mathrm{mM},\left[\mathrm{CH}_{2} \mathrm{~N}\right.$ $\left.\left(\mathrm{CH}_{2} \mathrm{COO}\right)_{2}\right]_{2} \mathrm{FeNa} 0.05 \mathrm{mM}, \mathrm{Na}_{2} \mathrm{SiO}_{3} .5 \mathrm{H}_{2} \mathrm{O}$ $0.06 \mathrm{mM}, \mathrm{KH}_{2} \mathrm{PO}_{4} 1.00 \mathrm{mM}, \mathrm{H}_{3} \mathrm{BO}_{3} 50 \mu \mathrm{M}$, $\mathrm{MnCl}_{2} .4 \mathrm{H}_{2} \mathrm{O} 15 \mu \mathrm{M}, \mathrm{ZnSO}_{4} .7 \mathrm{H}_{2} \mathrm{O} 0.8 \mu \mathrm{M}$, $\mathrm{CuSO}_{4} .5 \mathrm{H}_{2} \mathrm{O} 0.3 \mu \mathrm{M} ; \mathrm{NaMoO}_{4} \cdot 2 \mathrm{H}_{2} \mathrm{O} 0.1 \mu \mathrm{M}$ ) was used to mix with soil to the equivalent soil moisture (170 $\mathrm{g} \mathrm{kg}^{-1}$, gravimetric soil moisture content). The concentration of nitrogen and phosphorus ( $\mathrm{mg} \mathrm{kg}^{-1}$ soil) in the background (un-amended) and amended soil (with nutrients added) is shown in Table 1. The $\mathrm{N}$ level of uniform treatment was equivalent to $200 \mathrm{~kg} \mathrm{~N} \mathrm{ha}^{-1}$ in the field.

A single pre-germinated seed (two-day old) was placed at the midpoint in the top of the rhizotron against the glass face at a depth of $1 \mathrm{~cm}$. Once planted, the seed received no further watering, simulating a terminal drought and avoiding any redistribution of nutrients. Twice each week root elongation against the glass face (Fig. 1) was traced onto transparent films. The rhizotron was separated into $14(20 \times 20 \mathrm{~cm})$ areas to observe root growth. The length of traced roots on the transparency film was determined with the use of a scanner running WinRhizo software (Regent Instruments Inc., Quebec, QC, Canada). At harvest, shoot dry weight, total nitrogen and carbon content were measured with a Leco combustion analyser.

A soil moisture profile probe (Model PR1, Delta-T Devices, Burwell, UK), incorporated in approximately a third of the width of each rhizotron, monitored soil moisture content daily at multiple depths in the soil profile: 10, 20, 30, 40, 60 and $100 \mathrm{~cm}$ (Whalley et al. 2004). The volume of soil sampled the profile probe is heavily weighted to the surface of the probe and the region outside the rhizotron had a negligible effect on the instrument. At harvest, gravimetric soil moisture content $\left(\theta_{g}\right)$ of each $10 \mathrm{~cm}$ layer was measured. Plant water-use was calculated by the following equation,

Water use $(\mathrm{mm})=\sum_{t=1}^{n}\left(\theta_{g} \rho D i\right)$

$\theta_{g}\left(\mathrm{~g} \mathrm{~g}^{-1}\right)$ is the gravimetric soil moisture content, $\rho$ is the dry bulk density and $n$ is the number of soil layers of thickness $D$ (rhizotron was separated to 15 layers). Soil nitrate and ammonium were measured using the Skalar SANPLUS.

\section{Statistics}

The experiment was performed twice with 2 replicates of each treatment. This degree of replication is consistent with other rhizotron studies (e.g. Fender et al. 2013). The data were analysed as a fully randomized experiment. The data were analysed with Genstat ${ }^{\circledR}$ V16 (VSN International Ltd). To analyse root growth data periods of growth were grouped into set of 5 days and 4 groups were chosen for separate analysis ( 10 to 15,35 to 40,55 to 60 and 60 to 65 days). The residual diagnostic plots indicated that a transformation was needed to stabilize the variance. The transformation used was the 


\section{Nutrient}

$0-40 \mathrm{~cm}$

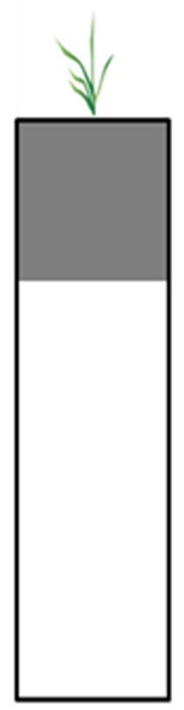

\section{Nutrient}

$60-100 \mathrm{~cm}$

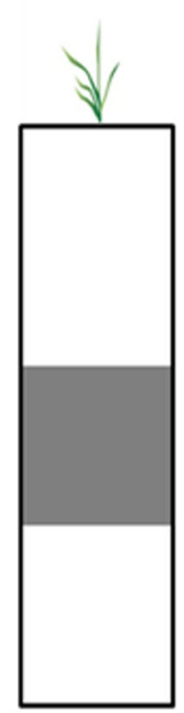

\section{Water}

B

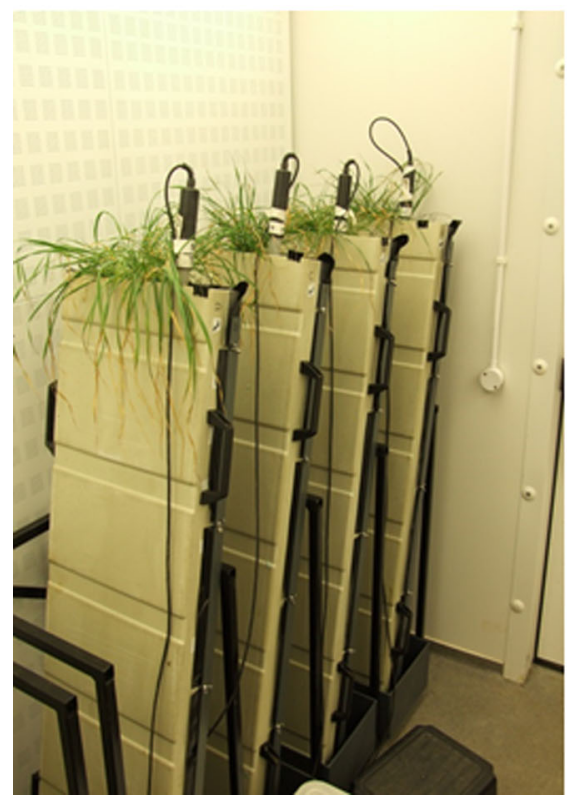

Fig. 1 The schematic representation (a) of the experiment, three nutrient scenarios were placed as (1) nutrient-rich profile (Uniform, $0-140 \mathrm{~cm})$, (2) nutrient-rich surface layer $(0-40 \mathrm{~cm})$ and (3) a nutrient depleted surface layer with nutrient-rich layer at depth $(60-100 \mathrm{~cm})$. In nutrient poor areas, deionised water (Water) was

\section{Nutrient}

\section{C}

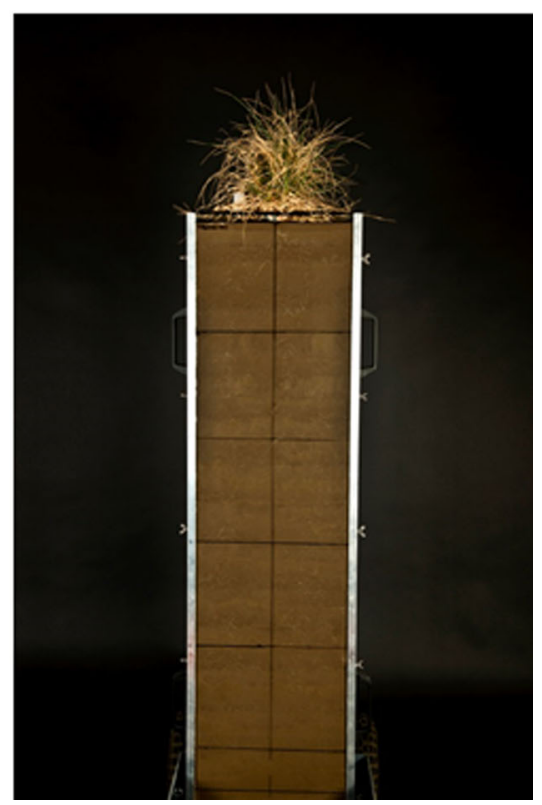

added to instead of Hoagland's nutrient solution (Nutrient). The soil-filled rhizotrons were mounded in a rack at an incline of $15^{\circ}$ at $\mathrm{CE}$ room (b). Soil moisture was monitored with dielectric probes. Root growth could be recorded by observing roots elongating against a glass face (c) 
Table 1 The concentration of total nitrogen and phosphorus ( $\mathrm{mg} \mathrm{kg}^{-1}$ soil) in the background (sample soil) and amended soil (soil to which nutrient was added). Nutrient placement was uniform (homogenous nutrient concentration throughout the soil profile), nutrient in the surface layer from 0 to $40 \mathrm{~cm}$ or nutrient in the deep layer from 60 to $100 \mathrm{~cm}$

\begin{tabular}{lll}
\hline & Background soil & Amended soil \\
\hline $\mathrm{NH}_{4}{ }^{-\mathrm{N}}+\mathrm{NO}_{3}{ }^{-} \mathrm{-N}$ & 25.9 & 68.1 \\
$\mathrm{PO}_{4}{ }^{-} \mathrm{P}$ & 91.8 & 107.9 \\
\hline
\end{tabular}

square root of the original values. In order to capture the shapes of the response of transformed root length density with depth, spline modelling in REML was used. For our data root length density data we used estimates of the least significant difference (LSD) to allow comparison between any two means for a given time period. Other data were analysed by ANOVA or curve fitting.

\section{Results}

Soils

The water release characteristic of the soil used is shown in Fig. 2. The soil was mixed with water (or nutrient solution) at $170 \mathrm{~g} \mathrm{~kg}^{-1}$ (gravimetric moisture content), which corresponds to a matric potential of $-10 \mathrm{kPa}$. The negligible flow of water to depth during the early part to the experiment was confirmed by observation of stable water content readings from the PR1 Profile probe at all depths (data not shown). We also note that in the uniform nutrient treatment the water content at the bottom of the rhizotron at the end of the experiment was still nearly $170 \mathrm{~g} \mathrm{~kg}^{-1}$ indicating that no drainage occurred.

We estimated matric potential (Whalley et al. 2013) using the water release curve (Fig. 2) from measurements of water content. Estimates of matric potential between 35 and 40 days are shown in Fig. 3. It should be noted that these estimates are somewhat imprecise, due to the non-linear nature of the water release curve at low water contents (see Fig. 2). The water release curve is sensitive to soil density and although both the rhizotrons and cores used to determine the water release characteristics were packed to the same density, they may not be identical. Nevertheless, the data in Fig. 3 shows that in the treatment with uniform nutrient content, the surface layer was dryer and hence stronger (Whalley et al. 2007) than the other treatments, which is consistent with the

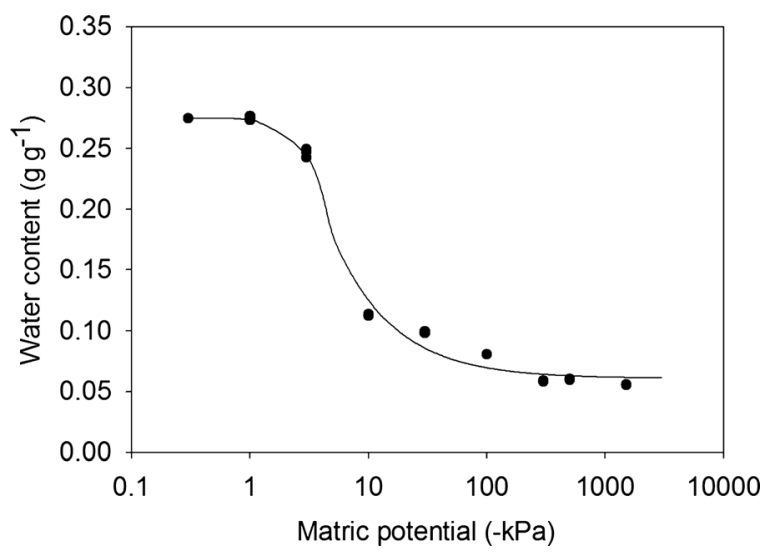

Fig. 2 Water release characteristics measured on re-packed samples of soil from Butt Close. The curve shown is fitted to the Van Genuchten soil water characteristic model (Vangenuchten 1980), $\theta=\left(\theta_{s}-\theta_{r}\right)\left[1+(a h)^{n}\right]^{-m}+\theta_{r}$ where $\theta$ is the water content $\left(\mathrm{g} \mathrm{g}^{-1}\right)$ and $\theta_{s}$ and $\theta_{r}$ are saturated and residual water contents $\left(\mathrm{g} \mathrm{g}^{-1}\right)$ respectively, $h(-\mathrm{kPa})$ is matric potential. $a, n$ and $m$ are empirical coefficients. The values of $a, n$ and $m$ are $0.3980,30.2920$ and 0.0286 respectively

greater root length density in the surface layers in that treatment at day 40 (see following section).

At terminal drought, wheat plants growing in the treatment with a nutrient-rich surface layer $(0-40 \mathrm{~cm})$ had dried the soil the most (Fig. 4a). This was consistent with the greater root length density (see following section) in this treatment compared to the other two treatments. At the end of the experiment the soil at depth was relatively well watered (Fig. 4) in all treatments.

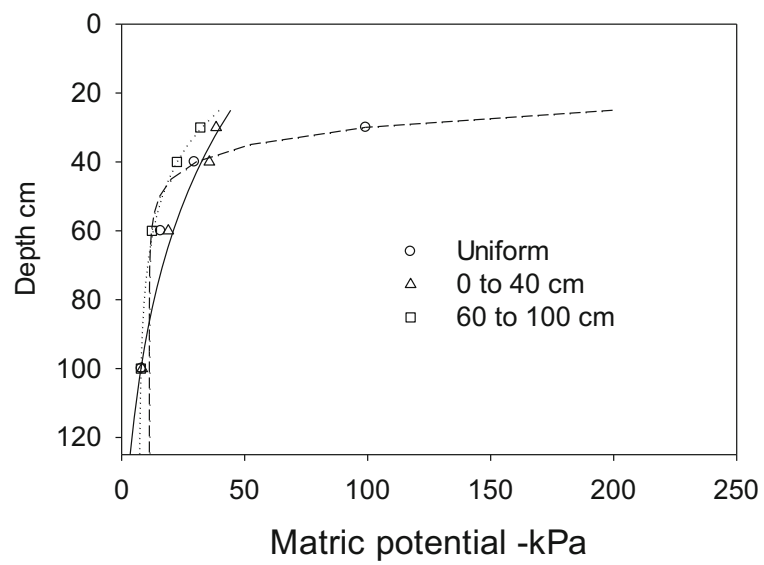

Fig. 3 Matric potential at day 40 was calculated from the water release curve (Vangenuchten 1980) (Fig. 2). Matric potential data were fitted to the function $\psi=A+B \exp (R d)$ where $A, B$ and $R$ are fitted parameters and $d$ is depth. Grouped regression revealed that these relations were significantly different from each other at $P=0.028$ 


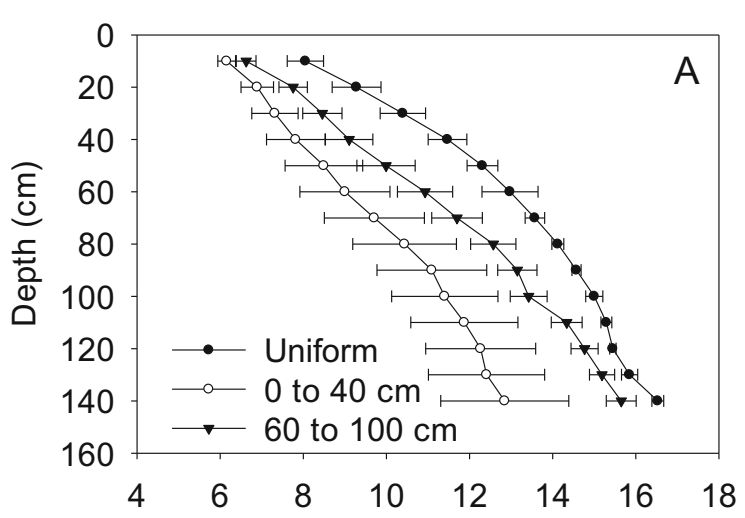

Soil moisture content ( $\%$ by dry weight)
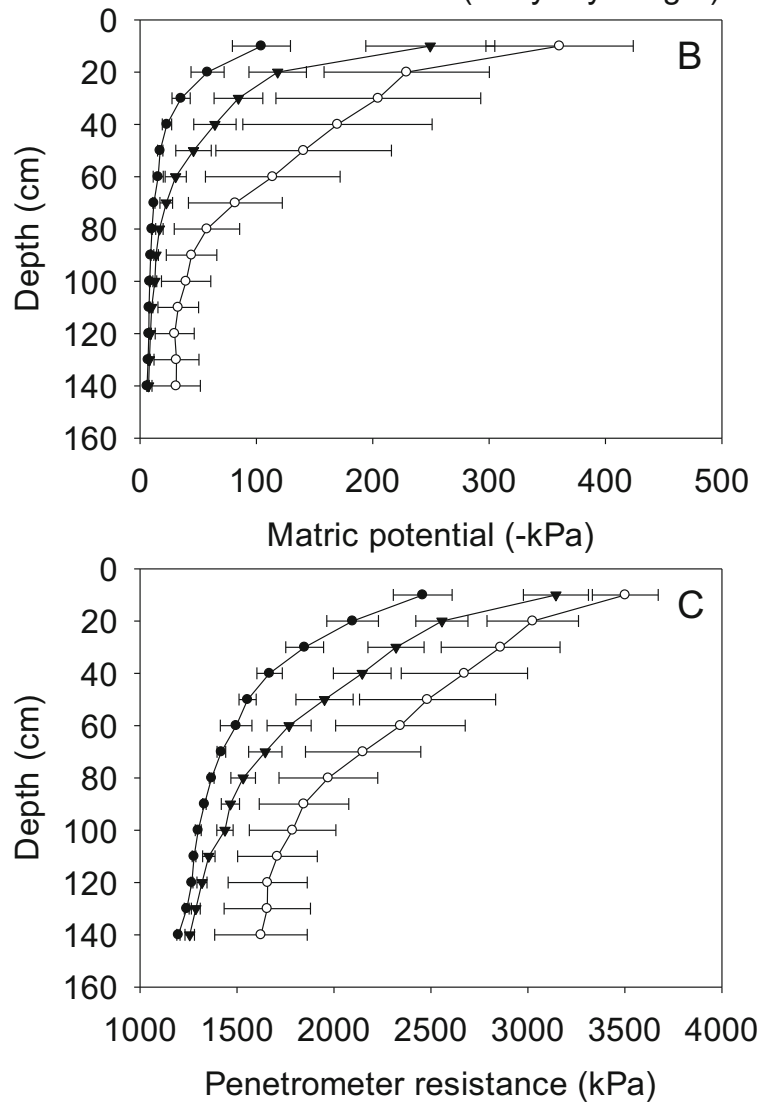

Fig. 4 Final profiles of the soil moisture content, matric potential and penetrometer resistance at terminal drought (Days 65). Water content was determined from oven drying of soil cores. Matric potential was calculated from the water release curve (Vangenuchten 1980) (Fig. 2). The penetrometer resistance was calculated by the equation of $\log _{10} Q=0.35( \pm 0.009) \log _{10} \sigma_{W^{+}}$ $0.93( \pm 0.0572) \rho+1.2623( \pm 0.0832)$ (Whalley et al. 2007), where $Q(\mathrm{kPa})$ is the penetrometer resistance, $\sigma_{W}(\mathrm{kPa})$ is effective stress and $\rho\left(\mathrm{g} \mathrm{cm}^{-3}\right)$ is the bulk density $\left(1.5 \mathrm{~g} \mathrm{~cm}^{-3}\right.$ of rhizotron soil in the experiment here). The standard error of the mean is indicated
Rhizotrons and plant growth

Different horizontal stratification of nutrient placement had a great effect on root distribution with depth (Fig. 5). At days 35 to 40 the root length density in the top $40 \mathrm{~cm}$ was simply related to the nutrient placement. However, in deeper layers root length density was not related to soil nutrient concentration. Following terminal drought at the end of the experiment (Days 60 to 65), deeper roots (below $1 \mathrm{~m}$ ) were most abundant in the rhizotrons which only had a surface $(0-40 \mathrm{~cm})$ layer of nutrientrich soil. Uniform nutrient placement resulted in the fewest deep roots.

Photographs of the roots at the end of the experiment revealed many observations reported in field-grown plants (Fig. 6). Gaps that developed between the root and the soil were most likely due to root shrinkage (Fig. 6a), since the loamy sand soil has very small shrinkage. Root hairs (Fig. 6b) grew between the root and soil. Roots that grew against the glass face of the rhizotron were often clumped (Fig. 6c) and not distributed uniformly.

Although ANOVA showed that the shoot dry matter was similar for the different treatments ( $P=0.069,2 \mathrm{df}$ ), shoot growth was closely correlated to water-use irrespective of the nutrient placement (Fig. 7). The effect of nutrient distribution was to alter the spatial distribution of roots (Fig. 5) and thereby influence the access to soil water. A uniform nutrient distribution throughout the rhizotron was the least effective approach for maximizing water uptake (Fig. 4). The $\mathrm{N}$ concentration in the shoots was not greatly affected by the distribution of $\mathrm{N}$ in the soil and there was no evidence that the shoot growth was limited by low $\mathrm{N}$ uptake (Table 2) or soil nutrient availability at the end for the experiment (Table 3 ).

\section{Discussion}

The most striking result is that soil profiles which are uniformly rich in nutrients were the least effective in promoting deep rooting and water uptake from depth (Fig. 7). While nutrient-rich conditions triggered root proliferation, as seen in the treatment with a nutrientrich surface layer (Fig. 5), it was surprising that higher root growth was not seen at all layers in the treatment uniformly rich in nutrients. A possible explanation is that the greater root growth, as observed initially in the surface layers of this treatment, resulted in more intense soil 
Day 10 to 15

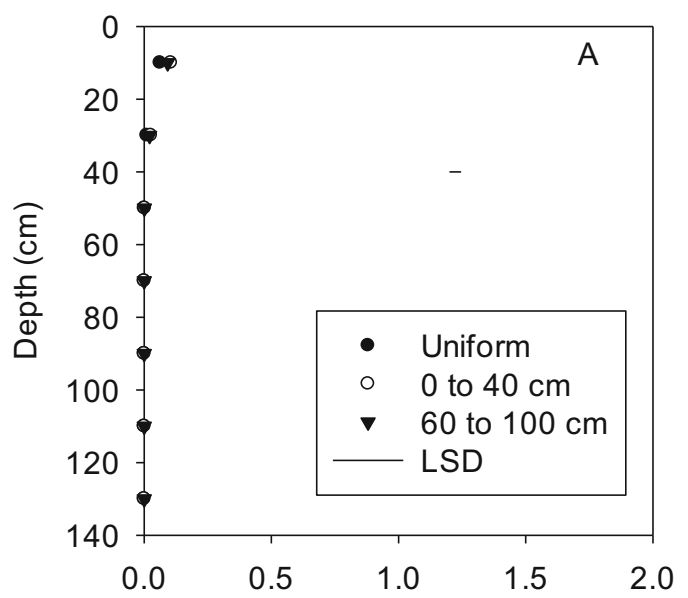

Square root [Root length density $\left(\mathrm{cm} \mathrm{cm}^{-2}\right)$ ]

Day 35 to 40

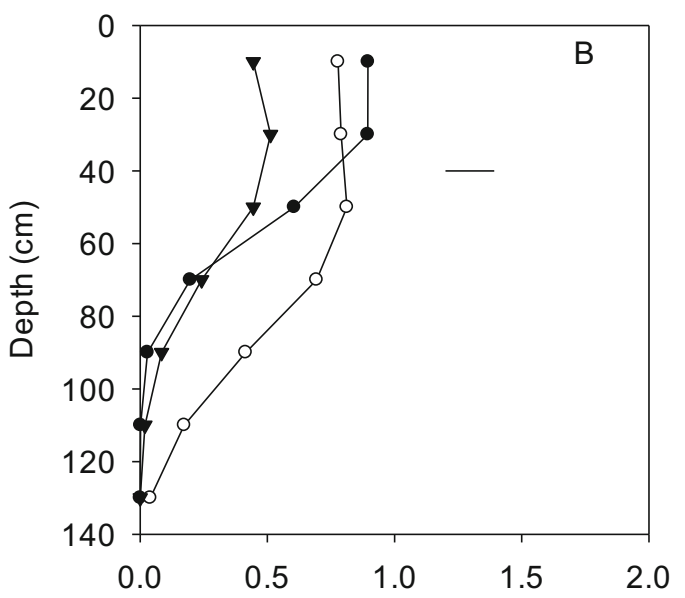

Square root [Root length density $\left(\mathrm{cm} \mathrm{cm}^{-2}\right)$ ]

Fig. 5 Root profiles with depth at different growth stages. Values are mean of four replicates of the period of 5 days. The horizontal bars in each graph indicate the size of the least significant

drying and increased soil mechanical impedance (Fig. 3), such that the root elongation may have been inhibited by strong soil (Bengough et al. 2011; Jin et al. 2013).

Previously published work, which has been mainly restricted to the surface $10 \mathrm{~cm}$ shows that roots proliferate in nutrient-rich patches (Day et al. 2003; De Kroon and Mommer 2006; Kume et al. 2006; Jing et al. 2010; Croft et al. 2012), our data showed root growth at greater depths was not enhanced with a nutrient band placed between 60 and $100 \mathrm{~cm}$ (Fig. 5). Root growth and/or proliferation decreased with depth in the soil profile. A
Day 55 to 60

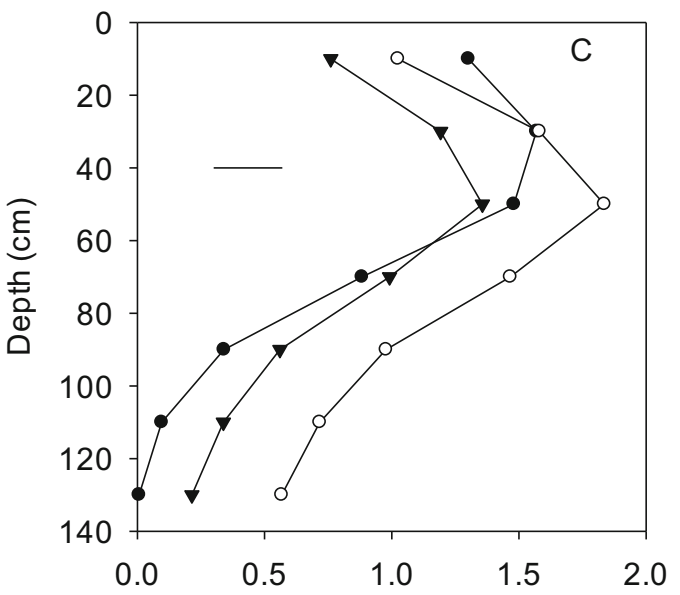

Square root [Root length density $\left(\mathrm{cm} \mathrm{cm}^{-2}\right)$ ]

Day 60 to 65

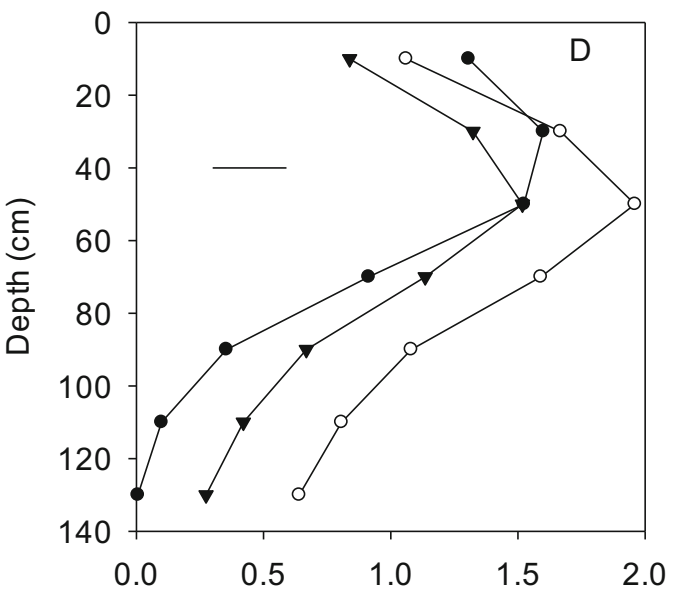

Square root [Root length density $\left(\mathrm{cm} \mathrm{cm}^{-2}\right)$ ]

differences (LSD) to allow comparison of any two means from any depth combination (df 116). All statistical comparisons are made on the square root scale, chosen to stabilize the variance

water-limited environment can suppress the branching in favour of deeper rooting (Chapman et al. 2011).

We allowed the soil to dry (Fig. 4) whereas in most other studies of heterogeneous nutrient distribution, soil water was maintained by hydroponics or specific culture (Robinson 1994; Trapeznikov et al. 2003). Drew (1975) grew barley (Hordeum vulgare cv. Proctor) in sand where horizontal stratification of nutrients was maintained by recirculating nutrient solution through a sand culture. Li et al. (2010) also grew white lupin (L. albus L. cv. Kiev) and He et al. (2003) grew rice (Oryza sativa L.) 

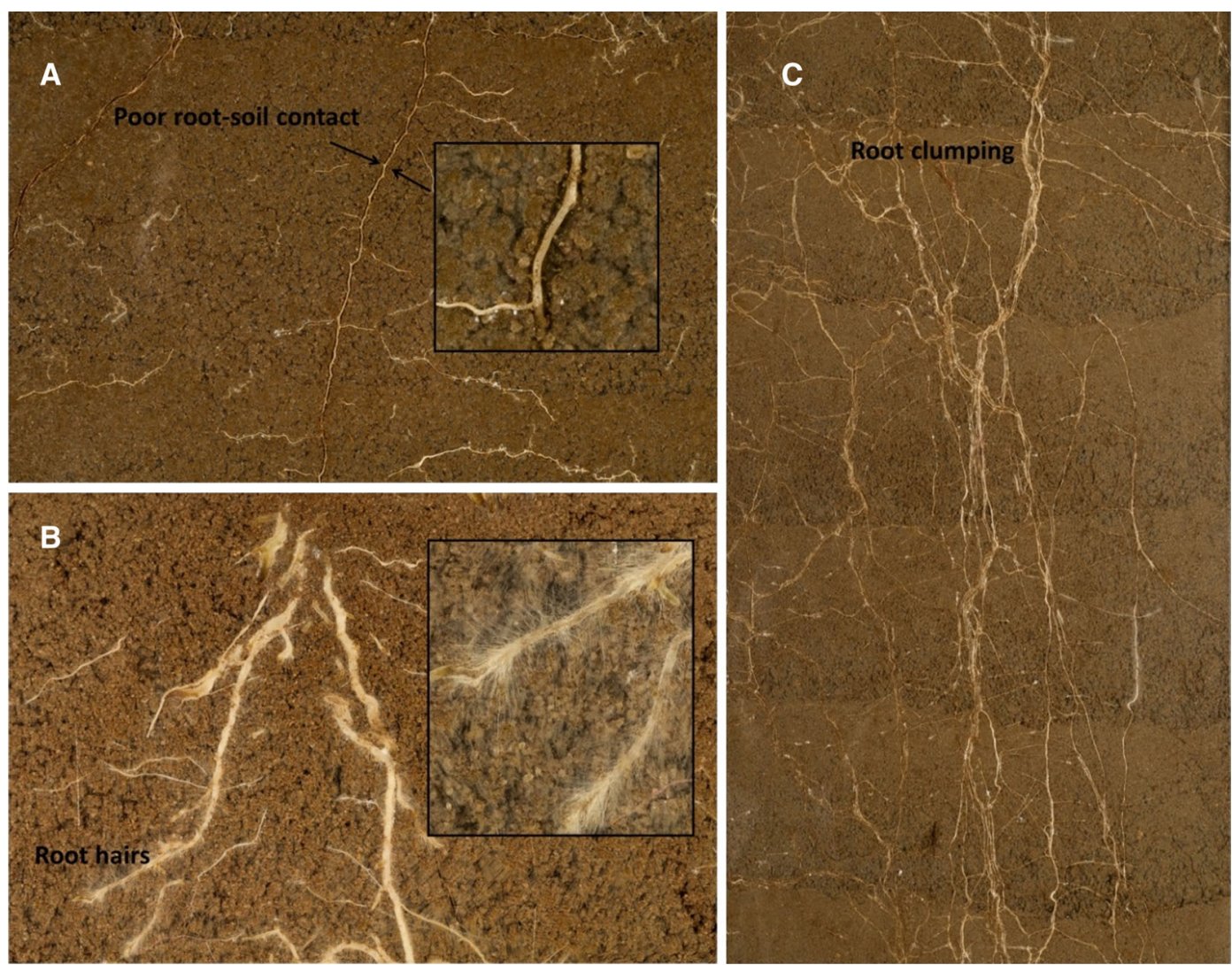

Fig. 6 Photographs of the roots at the end of the experiment. (a) Gaps between the root and the soil, (b) Root hairs grew between the root and soil, and (c) Roots were clumping against the rhizotron glass face

irrigated by capillary action through holes at the bottom of each pot during the period of the experiments. In our approach, horizontal nutrient stratification initially imposed in the rhizotrons were maintained by low soil

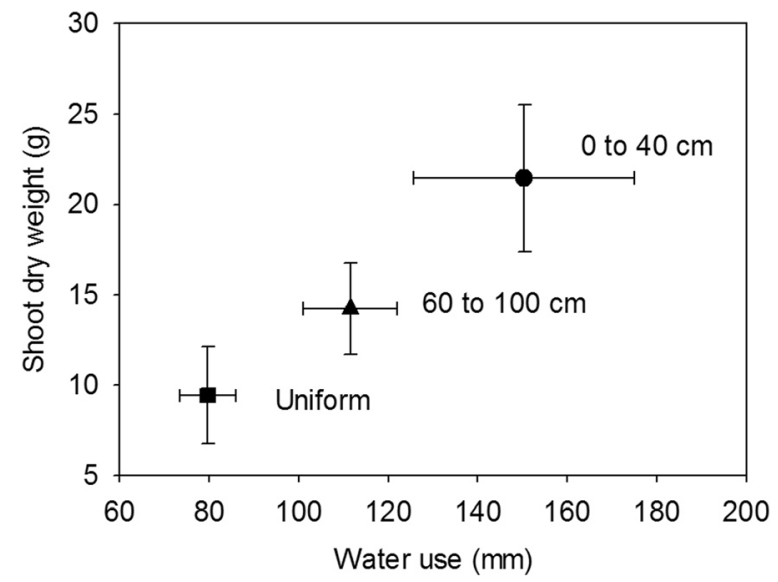

Fig. 7 The relationship between shoot dry biomass and water-use at the end of the experiment for different treatments. The standard errors are indicated conductivity to water; there was minimal water flow due to gravity, which was confirmed from measurements of the soil moisture meters by noting that the water content at a bottom of the rhizotron did not increase during the experiment.

Even under terminal drought, water was available in the rhizotron at relatively high matric potentials $(>-50$ $\mathrm{kPa}$ ) at depths greater than $80 \mathrm{~cm}$ (Fig. 4) and available for root uptake (Herkelrath et al. 1977; Dodd et al. 2010). At depth, root length density declined and roots were clumped in soil pores and channels with poor root-

Table 2 Nitrogen and carbon content of plant shoots. Values are mean \pm SE of four replicates, different lower case letters denote significant difference $(P<0.05)$ among treatments

\begin{tabular}{llll}
\hline \multicolumn{3}{c}{ Total N and C of shoot samples } \\
\hline & Uniform & $0-40 \mathrm{~cm}$ & $60-100 \mathrm{~cm}$ \\
$\mathrm{~N} \mathrm{~g} \mathrm{~kg}^{-1}$ & $34 \pm 2 \mathrm{a}$ & $35 \pm 1 \mathrm{a}$ & $36 \pm 2 \mathrm{a}$ \\
$\mathrm{C} \mathrm{g} \mathrm{kg}^{-1}$ & $416 \pm 3 \mathrm{a}$ & $422 \pm 3 \mathrm{a}$ & $412 \pm 4 \mathrm{a}$ \\
\hline
\end{tabular}


Table 3 Soil available nitrogen $\left(\mathrm{mg} \mathrm{kg}^{-1}\right)$ measured from different depths at the end of the experiment. Values are mean $\pm \mathrm{SE}$ of four replicates, different lower case letters denote significant difference $(P<0.05)$ among treatments

\begin{tabular}{llll}
\hline \multicolumn{4}{c}{ Treatments } \\
\hline Soil depth $(\mathrm{cm})$ & Uniform & $0-40 \mathrm{~cm}$ & $60-100 \mathrm{~cm}$ \\
20 & $22.0 \pm 2.5 \mathrm{a}$ & $12.6 \pm 2.0 \mathrm{~b}$ & $11.0 \pm 1.3 \mathrm{~b}$ \\
50 & $38.9 \pm 2.9 \mathrm{a}$ & $18.4 \pm 3.7 \mathrm{~b}$ & $22.7 \pm 4.0 \mathrm{~b}$ \\
80 & $45.9 \pm 3.6 \mathrm{a}$ & $25.4 \pm 5.6 \mathrm{~b}$ & $36.9 \pm 5.4 \mathrm{ab}$ \\
\hline
\end{tabular}

soil contact (Fig. 6). Root clumping may have been encouraged by roots growing along the rhizotron glass face (Fig. 6c) rather than clumping within pre-existing pores as is the case in the field (White and Kirkegaard 2010). However, even in our rhizotron this is likely to result in less effective water uptake compared with a more uniform spatial distribution of roots. Apart from poor spatial distribution of roots, gaps between the soil and roots (Fig. 6a) may also have contributed to poor water uptake. In our experiment this was almost certainly due to root shrinkage, because the loamy sand soil we used had minimal ability to shrink.

The North China Plain has a typical monsoonal climate with $70-80 \%$ of annual rainfall concentrated in the period from June to September (Hu et al. 2010a). Traditional farmer practice is to surface-apply $\mathrm{N}$ fertilizer before the heavy rainfall or flood irrigation (Fang et al. 2006). Thus, heavy rainfall and irrigation during the summer months in the North China Plain may cause great nitrate leaching in soil profile (Wang et al. 2010). Soil nitrate-N content in the top $90 \mathrm{~cm}$ of the soil profile should be maintained within the range of 154-159 $\mathrm{kg} \mathrm{N}^{-1}$ for high yield wheat production (Cui et al. 2013) and to reduce the $\mathrm{N}$ losses to the environment (Cui et al. 2006). This tends to result in deep nutrient-rich soil layers. In our experiment a uniformly nutrient-rich soil profile (with greater total nutrient load) did not increase shoot growth $(P=0.069)$ or plant nitrogen uptake (Table 2 ) relative to other treatments. These results are compatible with observations that traditional (excessive) $\mathrm{N}$ usage by Chinese farmers (Huimin, Shandong province, on average $369 \mathrm{~kg} \mathrm{~N}^{-1}$ to winter wheat $(n=370)$ ), does not significantly enhance grain yield (Cui et al. 2006, 2010; Peng et al. 2012; Zhang et al. 2012), however, there have been reported decreases in crop yield (Shen et al. 2013). These are likely to be due to the effect of nutrient placement on root growth (Fig. 5) and hence access to water (Fig. 7). Our study suggests that in regions which are likely to be water-limited (Li et al. 2005; Deng et al. 2006; Wang et al. 2008b; Fan et al. 2012), high rates of fertiliser application which over time result in deep nutrient-rich profiles, are likely to provide the least effective environment for water uptake by roots (Mi et al. 2010; Zhang et al. 2012).

\section{Conclusions}

In a laboratory simulation of a water-limited soil profile, using $1.4 \mathrm{~m}$ deep rhizotrons, root growth was greatly affected by the vertical distribution of nutrients. A treatment with a nutrient-rich surface layer with nutrient poor subsoil was the most effective at promoting deep rooting and water uptake. In a treatment with a deep nutrient-rich soil, to a depth of $1.4 \mathrm{~m}$, deep rooting was restricted as was water uptake. Shoot biomass was simply related to water-use irrespective of the spatial distribution of nutrients. We found that at the end of the experiment when the plants were at terminal drought, there was water at depth which was not accessed by the roots. Our experiments were performed in waterlimiting conditions with layered regions of nutrientrich soil; our results differed from those reported for the conjunctive application of nutrient and water in localized patches, which tend to show that roots are more responsive to nutrient-rich patches in soil.

Acknowledgments WRW, MAJP and RWA are funded through the BBSRC funded 20:20 Wheat ${ }^{\circledR}$ project at Rothamsted Research. KJ and JS are funded by the National Natural Science Foundation of China (Nos. 31330070, 30925024, 31121062) and Beijing Natural Science Foundation (6122021). KJ visited Rothamsted Research with a scholarship from China Scholarship Council. We thank Defra for support on project WU0121 which partly supported ICD.

Open Access This article is distributed under the terms of the Creative Commons Attribution License which permits any use, distribution, and reproduction in any medium, provided the original author(s) and the source are credited.

\section{References}

Bengough AG, Mckenzie BM, Hallett PD, Valentine TA (2011) Root elongation, water stress, and mechanical impedance: a review of limiting stresses and beneficial root tip traits. J Exp Bot 62:59-68

Chapman N, Whalley WR, Lindsey K, Miller AJ (2011) Water supply and not nitrate concentration determines 
primary root growth in Arabidopsis. Plant Cell Environ $34: 1630-1638$

Croft SA, Hodge A, Pitchford JW (2012) Optimal root proliferation strategies: the roles of nutrient heterogeneity, competition and mycorrhizal networks. Plant Soil 351:191-206

Cui ZL, Chen XP, Li JL, Xu JF, Shi LW, Zhang FS (2006) Effect of $\mathrm{N}$ fertilization on grain yield of winter wheat and apparent $\mathrm{N}$ losses. Pedosphere 16:806-812

Cui ZL, Zhang FS, Miao YX, Sun QP, Li F, Chen XP, Li JL, Ye YL, Yang ZP, Zhang Q, Liu CS (2008) Soil nitrate-N levels required for high yield maize production in the North China Plain. Nutr Cycl Agroecosys 82:187-196

Cui ZL, Chen XP, Zhang FS (2010) Current nitrogen management status and measures to improve the intensive wheat-maize system in China. Ambio 39:376-384

Cui ZL, Chen XP, Zhang FS (2013) Development of regional nitrogen rate guidelines for intensive cropping systems in China. Agron J 105:1411-1416

Day KJ, Hutchings MJ, John EA (2003) The effects of spatial pattern of nutrient supply on yield, structure and mortality in plant populations. J Ecol 91:541-553

De Kroon H (2007) Ecology - How do roots interact? Science 318: $1562-1563$

De Kroon H, Mommer L (2006) Root foraging theory put to the test. Trends Ecol Evol 21:113-116

Deng XP, Shan L, Zhang HP, Turner NC (2006) Improving agricultural water use efficiency in arid and semiarid areas of China. Agr Water Manage 80:23-40

Dodd IC, Egea G, Watts CW, Whalley WR (2010) Root water potential integrates discrete soil physical properties to influence ABA signalling during partial rootzone drying. J Exp Bot 61:3543-3551

Dodd IC, Whalley WR, Ober ES, Parry MJ (2011) Genetic and management approaches to boost UK wheat yields by ameliorating water deficits. J Exp Bot 62:5241-5248

Drew MC (1975) Comparison of the effects of a localised supply of phosphate, nitrate, ammonium and potassium on the growth of the seminal root system, and the shoot, in Barley. New Phytol 75:479-490

Drew MC, Saker LR (1975) Nutrient supply and growth of seminal root system in Barley.2. Localized, compensatory increases in lateral root growth and rates of nitrate uptake when nitrate supply is restricted to only part of root system. J Exp Bot 26:79-90

Drew MC, Saker LR (1978) Effects of direct drilling and ploughing on root distribution in spring barley, and on the concentrations of extractable phosphate and potassium in the upper horizons of a clay soil. J Sci Food Agr 29:201-206

Du TS, Kang SZ, Sun JS, Zhang XY, Zhang JH (2010) An improved water use efficiency of cereals under temporal and spatial deficit irrigation in north China. Agr Water Manage 97:66-74

Durieux RP, Kamprath EJ, Jackson WA, Moll RH (1994) Root distribution of corn - the effect of nitrogen-fertilization. Agron J 86:958-962

Fan MS, Shen JB, Yuan LX, Jiang RF, Chen XP, Davies WJ, Zhang FS (2012) Improving crop productivity and resource use efficiency to ensure food security and environmental quality in China. J Exp Bot 63:13-24

Fang QX, Yu Q, Wang EL, Chen YH, Zhang GL, Wang J, Li LH (2006) Soil nitrate accumulation, leaching and crop nitrogen use as influenced by fertilization and irrigation in an intensive wheat-maize double cropping system in the North China Plain. Plant Soil 284:335-350

Farley RA, Fitter AH (1999) The responses of seven co-occurring woodland herbaceous perennials to localized nutrient-rich patches. J Ecol 87:849-859

Fender A-C, Gasert D, Jungkunst HF, Fielder S, Beyer F, Schützenmeister K, Thiele B, Valtanen K, Polle A, Leuschner C (2013) Root-induced tree species effects on the source/sink strength for greenhouse gasses $\left(\mathrm{CH}_{4}, \mathrm{~N}_{2} \mathrm{O}\right.$ and $\mathrm{CO}_{2}$ ) of a temperate deciduos forest soil. Soil Biol BioChem 57:587-597

Forde B, Zhang HM (1998) Response: nitrate and root branching. Trends Plant Sci 3:204-205

Fransen B, Blijjenberg J, De Kroon H (1999) Root morphological and physiological plasticity of perennial grass species and the exploitation of spatial and temporal heterogeneous nutrient patches. Plant Soil 211:179-189

Gregory AS, Bird NRA, Whalley WR, Matthews GP, Young IM (2010) Deformation and shrinkage effects on the soil water release characteristic. Soil Sci Soc Am J 74:11041112

He Y, Liao H, Yan X (2003) Localized supply of phosphorus induces root morphological and architectural changes of rice in split and stratified soil cultures. Plant Soil 248:247256

Herkelrath WN, Miller EE, Gardner WR (1977) Water-uptake by plants. 1. Divided root experiments. Soil Sci Soc Am J 41: $1033-1038$

Hodge A (2004) The plastic plant: root responses to heterogeneous supplies of nutrients. New Phytol 162:9-24

Hodge A (2006) Plastic plants and patchy soils. J Exp Bot 57:401411

Hodge A (2010) Roots: the acquisition of water and nutrients from the heterogeneous soil environment. In: Lüttge U, Beyschlag W, Büdel B, Francis D (eds) Progress in botany 71. Springer, Berlin, pp 307-337

Hu KL, Huang YF, Li H, Li BG, Chen DL, White RE (2005) Spatial variability of shallow groundwater level, electrical conductivity and nitrate concentration, and risk assessment of nitrate contamination in North China Plain. Environ Int 31: 896-903

Hu KL, Li Y, Chen WP, Chen DL, Wei YP, Edis R, Li BG, Huang YF, Zhang YP (2010a) Modeling nitrate leaching and optimizing water and nitrogen management under irrigated maize in desert oases in Northwestern China. J Environ Qual 39: 667-677

$\mathrm{Hu}$ YK, Moiwo JP, Yang YH, Han SM, Yang YM (2010b) Agricultural water-saving and sustainable groundwater management in Shijiazhuang irrigation district, North China plain. J Hydrol 393:219-232

Hutchings MJ, John EA (2004) The effects of environmental heterogeneity on root growth and root/shoot partitioning. Ann Bot-London 94:1-8

Jin KM, Shen JB, Ashton RW, Dodd IC, Parry MJ, Whalley WR (2013) How do roots elongate in a structured soil? J Exp Bot 64:4761-4777

Jing JY, Rui YK, Zhang FS, Rengel Z, Shen JB (2010) Localized application of phosphorus and ammonium improves growth of maize seedlings by stimulating root proliferation and rhizosphere acidification. Field Crop Res 119:355-364 
Ju X, Liu X, Zhang F, Roelcke M (2004) Nitrogen fertilization, soil nitrate accumulation, and policy recommendations in several agricultural regions of China. Ambio 33:300-305

Ju XT, Kou CL, Zhang FS, Christie P (2006) Nitrogen balance and groundwater nitrate contamination: comparison among three intensive cropping systems on the North China plain. Environ Pollut 143:117-125

Kendy E, Molden DJ, Steenhuis TS, Liu C (2003) Policies drain the North China plain: agricultural policy and groundwater depletion in Luancheng County, 1949-2000. IWMI research report. International Water Management Institute, Colombo

King J, Gay A, Sylvester-Bradley R, Bingham I, Foulkes J, Gregory P, Robinson D (2003) Modelling cereal root systems for water and nitrogen capture: towards an economic optimum. Ann Bot-London 91:383-390

Kirkegaard JA, Lilley JM, Howe GN, Graham JM (2007) Impact of subsoil water use on wheat yield. Aust J Agr Res 58:303315

Kume T, Sekiya N, Yano K (2006) Heterogeneity in spatial Pdistribution and foraging capability by Zea mays: effects of patch size and barriers to restrict root proliferation within a patch. Ann Bot-London 98:1271-1277

Li J, Inanaga S, Li Z, Eneji AE (2005) Optimizing irrigation scheduling for winter wheat in the North China plain. Agr Water Manage 76:8-23

Li HG, Shen JB, Zhang FS, Lambers H (2010) Localized application of soil organic matter shifts distribution of cluster roots of white lupin in the soil profile due to localized release of phosphorus. Ann Bot-London 105:585-593

Lilley JM, Kirkegaard JA (2011) Benefits of increased soil exploration by wheat roots. Field Crop Res 122:118-130

Liu XJ, Ju XT, Zhang FS, Pan JR, Christie P (2003) Nitrogen dynamics and budgets in a winter wheat-maize cropping system in the North China plain. Field Crop Res 83:111-124

Lopes MS, Reynolds MP (2010) Partitioning of assimilates to deeper roots is associated with cooler canopies and increased yield under drought in wheat. Funct Plant Biol 37:147-156

Lynch JP, Brown KM (2012) New roots for agriculture: exploiting the root phenome. Philo Trans of the Royal Soc B: Biol Sci 367:1598-1604

Mi GH, Chen FJ, Wu QP, Lai NW, Yuan LX, Zhang FS (2010) Ideotype root architecture for efficient nitrogen acquisition by maize in intensive cropping systems. Sci China Life Sci 53: 1369-1373

Morison JIL, Baker NR, Mullineaux PM, Davies WJ (2008) Improving water use in crop production. Philo Trans of the Royal Soc B: Biol Sci 363:639-658

Passioura JB (1977) Grain-yield, harvest index, and water-use of wheat. J Aust I Agr Sci 43:117-120

Peng Y, Li X, Li C (2012) Temporal and spatial profiling of root growth revealed novel response of maize roots under various nitrogen supplies in the field. Plus One 7:e37726

Qiu SJ, Ju XT, Lu X, Li L, Ingwersen J, Streck T, Christie P, Zhang FS (2012) Improved nitrogen management for an intensive winter wheat/summer maize double-cropping system. Soil Sci Soc Am J 76:286-297

Richards RA (2008) Genetic opportunities to improve cereal root systems for dryland agriculture. Plant Prod Sci 11: $12-16$

Robinson D (1994) The responses of plants to nonuniform supplies of nutrients. New Phytol 127:635-674
Roycewicz P, Malamy JE (2012) Dissecting the effects of nitrate, sucrose and osmotic potential on Arabidopsis root and shoot system growth in laboratory assays. Philos T R Soc B 367: 1489-1500

Sharp RE, Silk WK, Hsiao TC (1988) Growth of the maize primary root at low water potentials.1. Spatial-distribution of expansive growth. Plant Physiol 87:50-57

Shen J, Li C, Mi G, Li L, Yuan L, Jiang R, Zhang F (2013) Maximizing root/rhizosphere efficiency to improve crop productivity and nutrient use efficiency in intensive agriculture of China. J Exp Bot 64:1181-1192

Tittonell P, Vanlauwe B, Leffelaar PA, Shepherd KD, Giller KE (2005) Exploring diversity in soil fertility management of smallholder farms in western Kenya: II. Within-farm variability in resource allocation, nutrient flows and soil fertility status. Agric Ecosyst Environ 110:166-184

Trachsel S, Kaeppler SM, Brown KM, Lynch JP (2013) Maize root growth angles become steeper under low $\mathrm{N}$ conditions. Field Crop Res 140:18-31

Trapeznikov VK, Ivanov II, Kudoyarova GR (2003) Effect of heterogeneous distribution of nutrients on root growth, ABA content and drought resistance of wheat plants. Plant Soil 252:207-214

Van Der Weele CM, Spollen WG, Sharp RE, Baskin TI (2000) Growth of Arabidopsis thaliana seedlings under water deficit studied by control of water potential in nutrient-agar media. $\mathrm{J}$ Exp Bot 51:1555-1562

Vangenuchten MT (1980) A closed-form equation for predicting the hydraulic conductivity of unsaturated soils. Soil Sci Soc Am J 44:892-898

Verslues PE, Ober ES, Sharp RE (1998) Root growth and oxygen relations at low water potentials. Impact of oxygen availability in polyethylene glycol solutions. Plant Physiol 116:1403-1412

Walch-Liu P, Forde BG (2008) Nitrate signalling mediated by the NRT1.1 nitrate transporter antagonises L-glutamate-induced changes in root architecture. Plant J 54:820-828

Wang QX, Wang P, Yang XY, Zhai ZX, Wang XL, Shen LX (2003) Effects of nitrogen application time on root distribution and its activity in maize Zea mays L. Sci Agric Sin 36: $1469-1475$

Wang EL, Yu Q, Wu DR, Xia J (2008a) Climate, agricultural production and hydrological balance in the North China plain. Int J Climatol 28:1959-1970

Wang Y, Sheng LX, Li K, Sun HY (2008b) Analysis of present situation of water resources and counter measures for sustainable development in China. J of Water Resour and Water Eng 19:10-14

Wang HY, Ju XT, Wei YP, Li BG, Zhao LL, Hu KL (2010) Simulation of bromide and nitrate leaching under heavy rainfall and high-intensity irrigation rates in North China plain. Agr Water Manage 97:1646-1654

Wang Z, Van Kleunen M, During HJ, Werger MJA (2013) Root foraging increases performance of the clonal plant Potentilla reptans in heterogeneous nutrient environments. Plus One 8: e58602

Whalley WR, Bengough AG, Dexter AR (1998) Water stress induced by PEG decreases the maximum growth pressure of the roots of pea seedlings. J Exp Bot 49: 1689-1694

Whalley WR, Cope RE, Nicholl CJ, Whitmore AP (2004) In-field calibration of a dielectric soil moisture meter 
designed for use in an access tube. Soil Use Manage 20:203-206

Whalley WR, To J, Kay BD, Whitmore AP (2007) Prediction of the penetrometer resistance of soils with models with few parameters. Geoderma 137:370-377

Whalley WR, Watts CW, Gregory AS, Mooney SJ, Clark LJ, Whitmore AP (2008) The effect of soil strength on the yield of wheat. Plant Soil 306:237-247

Whalley WR, Ober ES, Jenkins M (2013) Measurement of the matric potential of soil water in the rhizosphere. J Exp Bot 64: 3951-3963

White RG, Kirkegaard JA (2010) The distribution and abundance of wheat roots in a dense, structured subsoil - implications for water uptake. Plant Cell Environ 33:133-148
White PJ, George TS, Gregory PJ, Bengough AG, Hallett PD, Mckenzie BM (2013) Matching roots to their environment. Ann Bot-London 112:207-222

Wilkinson S, Davies WJ (2010) Drought, ozone, ABA and ethylene: new insights from cell to plant to community. Plant Cell Environ 33:510-525

Zhang FS, Cui ZL, Chen XP, Ju XT, Shen JB, Chen Q, Liu XJ, Zhang WF, Mi GH, Fan MS, Jiang RF (2012) Integrated nutrient management for food security and environmental quality in China. Adv Agron 116:1-40

Zhu ZL, Chen DL (2002) Nitrogen fertilizer use in China Contributions to food production, impacts on the environment and best management strategies. Nutr Cycl Agroecosys 63:117-127 